\title{
On A Frame of the Book
}

a talk on a work-in-progress (Leeds, England, July 1997)

\section{Erin Mouré}

\begin{abstract}
On A Frame of the Book d'Erin Mouré propose une discussion des enjeux ontologiques du travail poétique de Mouré et plus particulièrement des thèmes traités dans son dernier livre de poésie intitulé A Frame of the Book. Mouré parle de son livre en ces termes: " mon travail poétique actuel dans A Frame of the Book (dont le titre pourrait aussi être The Frame of a Book) est orienté vers une exploration plus profonde de ce qui constitue la responsabilité humaine : actes et conséquences, jugements et circonstances, ardeurs et peines. Les poèmes tentent de découvrir et d'articuler les mécanismes de toutes ces forces et leur façon de s'exercer dans l'organisme humain, 'la personne' et son 'agrégat sensoriel.' »
\end{abstract}

My poetry has always been haunted by concerns that press upon the ontological. In my body of work over the years, I've pursued a kind of questioning: what does it mean to love, to exist, to communicate? How does the social framework influence us? Limit us? What are the limits of "the person," of tenderness, of grace, of honesty, of speech? How do we situate ourselves as beings in civil society?

Through the years and books, I find fewer certitudes, in the "poetic" as in life itself. The book I completed most recently, Search Procedures, ends with a poem in which the last section presents simultaneously an image of human birth and a declaration of the beauty of thought: beauty not of sense but of sounds and signs: "a r yp al oî." Which brought me perilously close to silence, to being unable to continue, to that wall.

"We like this. We go on."

\section{1}

The work I'm currently writing, A Frame of the Book (also The Frame of a Book), is directed toward a more profound exploration of what constitutes human responsibility: act and consequence, judgement and circumstance, ardour and grief. The poems attempt to uncover and articulate the 
mechanisms of all these forces, and their ways of operating in the human organism, "the person," their "sensory aggregate." There are, in short, forces that link us, that make us "persons" and not simply organisms. These forces compel and hold me.

In all this, what is the place/role of the skin? Does the skin mark the body's limit? How can one rethink the skin? Does the skin still demarcate the borders of identity when we work with a computer, when we no longer see our interlocutors? What is the effect of distance on the human body, on a woman's body, on relations between women? Is distance also an "inevitable effect," thus a "fact," of the text? Does the text act like a skin? Like a libidinal band (after J.-F. Lyotard)?

We don't see each other, my readers and I - what is it then that constructs us as individuals, as "acts"? What are the limits of individual consciousness? Where are the borders of memory, of the construction of the present, the past, the future...

"More is involved than a brain-state" (Edelman 213).

This brings me to Donna Haraway's notion of the body - which says that the body's boundaries are socially-constituted, bodies are communication practices, coding devices. "If it were ever possible ideologically to characterize women's lives by the distinction of public and private domains... it is now a totally misleading ideology, even for the purpose of showing how both terms of these dichotomies really construct each other in practice and in theory. I prefer a network ideological image, suggesting the profusion of spaces and identities and the permeability of boundaries in the actual personal body and in the body politic."

And "organisms are not special natural entities, whether they are fetuses, plants, or bacteria; they are particular technological solutions to a production problem."

For me "the permeability of boundaries in the actual personal body" is a fact, much of selfness comes from contextualization with or through the other, from this play between autonomy and other. Even "will" to me is a flux force between bodies and not a static though insistent expression of the individual (à la romanticism).

This project is traversed by the urgency of desire. Because the skin in itself is a "desiring integument," and even the cartography of the skin in the cortex alters in response to tactile stimulation. But the "libidinal economy" delineated in my work is always traced as well by political economy, by the economic forces that hold us in a present. 
The body itself is a geography, and an economy. I am still drawn to Deleuze's description of Spinoza's two simultaneous views of the body: as an assemblage / confluence of particles (which have motions and rests, i.e. velocities) and as relational with other bodies (affecting and being affected by). Thus self and non-self are in irrevocable relationality (even if this is subject to constant redefinition, as is the "self," which is also in irrevocable relationality or motion). The boundaries of selfhood shimmer; in fact, it is not even proper to speak of "boundaries" that "shift"; so-called boundaries are just "shimmers," they are "in shifts," and this occurs outside the body (because different friends, beings, animal presences, landscapes, tactilities change you differently), and inside the body (because touch alters the brain... body map boundaries can shift as much because of touch alone...).

As such, the skin DESIRES to be presented, both inside the brain, in those maps, and outside, in relation to those others, to another, that other. The inside configuration(s) in fact RELIES to some extent on the shimmer of the outside, where touch comes from. Inside and outside in a sense become reversible, the inside is a kind of outside, the outside is necessary to make the inside realize it IS an inside... (eroking Lyotard's libidinal band).

Personal identity, I believe, is libidinally invested everywhere, in and through all this relationality.

The brain itself does not make a value distinction between body/mind, outside/inside. It seizes information without regard to source. The voice speaking on the screen is still a voice. We are extensional over virtual spaces; with computers, localities are extensible over and through what we know as the old boundaries of physical space. Economic globalization and digitalization are obviating national boundaries, and changing the nature of localities. Yes, we still inhabit and are coded by national territories. But ideas of space and boundaries are changing rapidly, and can't help but affect, reverberate, reconstitute the body's boundaries as well.

The brain itself maps information, reads it, in parts, overlapping. To see what we see we need dynamic brain processes/structures for movement, for edge, for colour, for shape, sound... but there is nowhere in the brain where a picture is assembled. We are shimmers, coalescences, coalitional, not fragments. If everything is a fragment, if the brain works in "fragments," then we no longer need this word that reflects a nostalgic possibility of a wholeness. If everything is a fragment and the whole is illusory, it makes no sense to talk of fragments. In the corporation where I worked, 
playing with the information environment, I watched how people actually absorb information: not in whole fashion, but partly, connected with their own culture/upbringing, and subject to noise interference from other communicative endeavours in their environment. In other words, information absorption is consistent with a network or coalescent model, not with any model that relies on visions of a "whole" structure.

Our interactions as persons, as women, are changing through technology and through social/economic shifts: the way we think, locate and combine information is changing, has changed.

- We produce bits of info from various sources

- The receiver of info can alter the message

- We draw or link diverse forces by proximity not logic

- It is sometimes impossible or unnecessary to view, account for, all the info (the web, hypertext)

- "Knowing" does not have to be data in your head - it is a locational and recombinatory device

The creation of ourselves as subjects is done continually, is part of a continual actactact. When what was known as a "fragment" turns out to have no whole to compare it to, no "idealized" whole that is not exclusionary or corrupted, the word "fragment" itself ceases to bear meaning. What "was" a "fragment" may prove to be sufficient to open us up to another space, an altered coalition of conditions.

\section{2}

In my texts I want to play with the notion of a "figure" that can emerge from data that is, or appears to be, "non-figurative." The work of portraitists, and the history of portraiture (from its start with the Etruscans) interests me and underpins my poetic research on what is the figurative, the figure. For me, as for the painter Francis Bacon, "the figure itself lies beyond the figurative," and "sensation is, rather, the effect of borders, of context, of difference" (Buci-Glucksmann).

What propels my texts is the word - "material," the torsional-figure, the body - not as container but as complex-implosion-traces linked to other complex-implosion-traces and taking its identity from this flux, this movement, and from the "imprévisable" (the unpredictable, the unaccountable) always present in and around ourselves.

The path this writing takes, or wants to take, is not that of narration. 
Because conventional narrative order tends to suppress too much to me, to reject too many choices, I'm trying to deal with emotional or designational "matters of fact" (Bacon/Deleuze) by setting aside narrative possibility, and using words as material to create torsional "scenes" that are Figures, that figurate being, human relationality, relationality especially between two women, between women as figures or beings who have been formed with great fear, with loss, who are coalescences of old griefs, who crave sweetness, for whom the great imperatives of physical proximity or distance bear emotional weight - writing works that are responded to, first of all, viscerally as sensation, almost "spatially"; then, rejected as non-coalescent by cortical processing; at the same time, that can't be entirely rejected, that haunt or ache, that speak a kind of facticity for the human person or girl and what holds us intact while at the same time letting us change incredibly - I work with boundaries in the head and the worry there, the extreme worry that alters boundaries, that is processed below consciousness, because thinking is not only a conscious act, it is a coding practice and is transversed by coding practices both in and outside the head.

The lines put a particular pressure at times on parts of speech, above all on the article, on definite and indefinite articles, to create an effect of zones swept of certitude, insisting thus on a more "global" reading of the text (as in Latin, for example, where the role of each word and what it designates is not fully evident until one reads the sentence "globally"). In fact, the "scenes" work upon and within a problematic of reading, a problematic of "designation," searching for the "ressemblant qui sort du non-ressemblant" (Deleuze 75).

Francis Bacon said about painting that "it directly touches the nervous system"; I believe that this can be equally true of poetic form. Even recent neurobiological research indicates that it is the unconscious that interprets sensory data, that anticipates and determines the organism's next steps; very little of this process manifests itself finally at the conscious level. And here, the material substrate of the unconscious is, in effect, the nervous system, that extension of the brain (everywhere) in the body.

My work relies on my capacity to force the borders and density of language; to use words as "material" means attentiveness to the convulsive, torsional power of words, of transcription, of syllables as marks, of "sounds like," of "means," of abrasion, erasure, gaps, cries. I still find myself every time, no matter what I start writing "about," to be writing sexualized or sexually-charged language or text or speech, and to be con- 
fronting a kind of sexual, phenomenological "order" to the linguistic one, to be foregrounding an extremely insistent, physically embedded desire, a carnality that infuses all acts, all potential for human bearing, grief, affection, responsibility, consequence. The usual images of girls fucking are not what you will find in my work, for the most part. Even so, I explore, move forward into the wreckage of being, human being, in and out of my sexualized, lesbian body, which to me is not marginal but is the locus of any possible figuration of a "me," any possible utterance or inscription (which are also relationalities, velocities), and is contiguous with the " $\mathrm{me}^{\text {" }} \mathrm{s}$ of others. And that contiguity too, is critical to me as a conscious being: relationality is part of what defines me as a body, as present, as conscious, as imbricated.

This work on language also broaches notions of civil life, of what one has in common with others, and notions of justice. How our beings are socially, culturally, constructed, and constructed as well in and through technology(ies), which flatten \& twist space/time notionality... making any conventional notion of "presence" or "self-presence" or even "corporeality" virtually untenable. As the French philosopher Jean-François Lyotard said, "Justice here does not consist merely in the observance of the rules; as in all games it consists in working at the limits of what the rules permit, in order to invent new moves, perhaps new rules and therefore new games" (100).

\section{3}

With A Frame of the Book / The Frame of a Book, I am trying to write a book of poems where the texts take on all the questions and aims I've mentioned, one that pushes and disturbs the limits of poetry. Where a bodily pressure on words and form is evident. A poetry not exempt from narration, but for which narration is a textual strategy among others. A poetry that works with the figural from a "pictorial" point of view, not as representation but as torsional designation of a being. These things I must explore without constraint, but I do so out of a body and sensibility that is sexualized, that is specifically lesbian (though all the possible consequences of that locality are not defined but open), that is specifically gendered female, and that is socialized female. Out of these explorations, I believe, can come some new ways of seeing sexuality, sexual imagery, sexual feeling, along with civic responsibility and civic "being." Contributing to a community of such endeavours so that multiple refractions, questions, reverberatory echoes are possible. 


\section{Works Cited}

Buci-Glucksmann, C. “Le plissé baroque de la peinture." Magazine littéraire 257 (1987).

Deleuze, Gilles. Francis Bacon: Logique de la sensation. 4e édition. Paris: Éditions de la différence, 1996.

Edelman, Gerald. The Remembered Present: A Biological Theory of Consciousness. New York: Basic Books, 1989.

Haraway, Donna. "The Ironic Dream of a Common Language for Women in the Integrated Circuit: Science, Technology, and Socialist Feminism in the 1980s or A Socialist Feminist Manifesto for Cyborgs." WWW. 1983. (An early version of "A Cyborg Manifesto: Science, Technology, and Socialist-Feminism in the Late Twentieth Century," in Simians, Cyborgs and Women: The Reinvention of Nature. New York: Routledge, 1991. 14981.)

Lyotard, Jean-François and Jean-Loup Thébaud. Just Gaming. Trans. Wlad Godzich. Minneapolis: U of Minnesota P, 1989.

Mouré, Erin. A Frame of the Book, also called The Frame of a Book. Toronto: House of Anansi, 1999. 